\title{
Hidrogeoquímica e qualidade das águas superficiais na bacia do Alto Jacaré- -Pepira (SP), Brasil
}

\author{
Ludmila Vianna BATISTA ${ }^{1}$ \& Didier GASTMANS ${ }^{2}$
}

1 Programa de Pós-graduação em Geociências e Meio Ambiente, Universidade Estadual Paulista, Campus Rio Claro. Av. 24A, 1515, CEP 13506-900, Rio Claro, SP, Brasil.E-mail: ludvbatista@yahoo.com.br.

2 Centro de Estudos Ambientais, Universidade Estadual Paulista, Campus Rio Claro. E-mail: gastmans@rc.unesp.br.

Recebido em 11/2014. Aceito para publicação em 09/2015.

Versão online publicada em 11/12/2015 (www.pesquisasemgeociencias.ufrgs.br)

\begin{abstract}
Resumo - Estudos hidrogeoquímicos vem sendo utilizados com o objetivo de se definir as reações químicas resultantes da interação água-rocha que são responsáveis por fornecer as características naturais das águas superficiais, bem como indicar os efeitos da ação antrópica sobre a sua qualidade, e assim averiguar interferências na disponibilidade hídrica. Inserida na bacia hidrográfica do Rio Tietê-Jacaré, a sub-bacia do Alto Jacaré Pepira (SP) foi selecionada para este estudo devido a sua relativa complexidade geológica e inserção em uma importante área de recarga do Sistema Aquífero Guarani (SAG), na qual os recursos hídricos representam uma importante atração turística, especialmente para a cidade de Brotas (SP). Foram coletadas 17 amostras de águas superficiais, com o objetivo de determinar o Índice de Qualidade da Água (IQA), bem como avaliar sua composição química. Os valores de IQA variaram de 63 a 82, indicando que a qualidade da água pode ser considerada "Boa". A condutividade elétrica apresenta boa correlação com as concentrações de sólidos totais em suspensão e sólidos totais dissolvidos. Quimicamente as águas da bacia são caracterizadas pela presença de $\mathrm{HCO}_{3}{ }^{-}$como principal ânion, com concentrações variando de $4,12 \mathrm{mg} \mathrm{L}^{-1}$ a 44,50 $\mathrm{mg} \mathrm{L}^{-1}$, e como principais cátions o $\mathrm{Ca}^{2+}$ e o $\mathrm{Mg}^{2+}$, com concentrações variando de $0,38 \mathrm{mg}$ $\mathrm{L}^{-1}$ a $11,60 \mathrm{mg} \mathrm{L}^{-1}$ e de $0,55 \mathrm{mg} \mathrm{L}^{-1}$ a 3,20 $\mathrm{mg} \mathrm{L}^{-1}$, respectivamente, o que classifica as águas como bicarbonatadas-cálcicas ou magnesianas. A avaliação global das amostras possibilitou a constatação da pequena influência exercida pela ação antrópica sobre os corpos d'água, refletida nos valores de IQA e nas baixas concentrações de $\mathrm{Cl}^{-}$e $\mathrm{NO}_{3}$ : A dissolução e intemperismo dos minerais presentes nas rochas e no solo da área de estudo são os processos geoquímicos responsáveis pela composição da água superficial na sub-bacia do Alto Jacaré-Pepira.
\end{abstract}

Palavras-chave: Hidrogeoquímica, interação água-rocha, IQA, qualidade da água, Rio Jacaré-Pepira.

\begin{abstract}
Hidrogeochemistry AND WATER QUALITY INDEX FRom ALto JACARÉ-PEPIRA WATERSHED (SP), BRAZIL. Hydrogeochemical studies have been used in order to define chemical reactions produced by water-rock interactions that are responsible to imprint the natural characteristics of surface water, as well as indicate the effects of anthropic activities over water quality, providing information about water availability. Located in Tietê-Jacaré Basin, the Upper Jacaré-Pepira watershed was selected for this study due to its relative geological complexity, to be inserted in an important recharge area of the Guarani Aquifer System (GAS), in which water resources are an important tourist attraction, especially for the city of Brotas (SP). Seventeen river water samples have been collected, in order to determine the Water Quality Index (WQI) as well as evaluate their chemical composition. WQI values vary from 63 to 82, and the water quality classified as "Good". Electrical conductivity presents strong correlation with total suspended solids and total dissolved solids. The main anion present in water composition is $\mathrm{HCO}_{3}{ }^{-}$showing concentrations varying from $4.12 \mathrm{mg}$ $\mathrm{L}^{-1}$ to $44.50 \mathrm{mg} \mathrm{L}^{-1}$, and $\mathrm{Ca}^{2+}$ and $\mathrm{Mg}^{2+}$ as the main cations, presenting concentrations ranging from $0.38 \mathrm{mg} \mathrm{L}^{-1}$ to $11.60 \mathrm{mg} \mathrm{L}^{-1}$ and $0.55 \mathrm{mg} \mathrm{L}^{-1}$ to $3.20 \mathrm{mg} \mathrm{L}^{-1}$, respectively. Based on chemical composition, river waters were classified as calcium or magnesium bicarbonate type. The overall assessment of the samples indicated the little influence of anthropic activities over water bodies, revealed by WQI values and low concentrations of $\mathrm{Cl}^{-} \mathrm{NO}_{3}$. Dissolution and weathering of minerals forming rocks and soil from study area are the main geochemical process responsible by final water chemical composition in the Upper Jacaré-Pepira watershed.
\end{abstract}

Keywords: Hydrogeochemistry, water-rock interaction, WQI, water quality, Jacaré-Pepira River. 


\section{Introdução}

A gestão integrada dos recursos hídricos deve levar em consideração as interações existentes entre as águas superficiais e subterrâneas, tratando o recurso como único e parte de um sistema integrado, dinâmico e complexo (Castany, 1971; Winter et al., 1971). Tal conexão deve ser considerada em estudos de planejamento, recuperação e preservação dos recursos hídricos e ambientais, uma vez que as interferências em um destes meios podem acarretar consequências em todo o sistema.

Segundo Meybeck \& Helmer (1992), a composição química, e portanto a qualidade das águas superficiais, está relacionada a diversos fatores, como: geologia, tipo de solo, clima, tipo e quantidade de cobertura vegetal e a influência antrópica. Em função das variações espaciais e temporais na composição química das águas superficiais, devido a processos internos e externos aos corpos d'água, caracterizados pela presença de substâncias inorgânicas ou orgânicas em diferentes concentrações e especiações, programas de monitoramento da qualidade da água de rios e corpos d'água vem sendo implantados gradativamente, especialmente devido à pressão de organizações nacionais e internacionais, entre elas a Organização Mundial da Saúde (OMS), que estabelece uma série de padrões e critérios para a potabilidade (ANA, 2005).

o Brasil vem produzindo, desde o início do século passado, leis e políticas que buscam consolidar uma forma de valorização dos recursos hídricos (CETESB, 2010), dos quais se destacam: a lei Federal n 9.433 de 08/01/1997 da Política Nacional de Recursos Hídricos, que define os instrumentos para a gestão das águas; a Resolução CONAMA no 357/2005 (CONAMA, 2005), que fixa os padrões de qualidade para diferentes usos e classes e a Portaria no 2.914 de 12/12/2011 do Ministério da Saúde (Brasil, 2011), que define água potável.

A composição química das águas dos rios do mundo e os processos geoquímicos responsáveis vem sendo estudada há várias décadas por diversos autores (Gibbs, 1972; Brikmann \& Santos, 1973; Stallard \& Edmond, 1981; Furch et al., 1982; Richey, 1985; Martinelli et al., 1989; Mortatti \& Probst, 1998; Gaillardet et al., 1999), revelando de maneira clara as relações entre a composição das águas superficiais e processos de evaporação, intemperismo químico, precipitação e impactos causados pela ação antrópica (Gibbs, 1972; Meybeck \& Helmer, 1992; Brennan \& Lowenstein, 2002).

Stallard \& Edmond (1981) apontam que as contribuições de $\mathrm{Na}^{+}, \mathrm{K}^{+}, \mathrm{Mg}^{2+}, \mathrm{Ca}^{2+}$ e $\mathrm{Cl}^{-}$para as cargas dissolvidas nas águas superficiais em uma ba- cia de drenagem estão associadas principalmente ao aporte por via atmosférica (sea salt), enquanto as concentrações de $\mathrm{K}^{+}, \mathrm{Ca}^{2+}, \mathrm{S}, \mathrm{P}$ e N relacionadas às contribuições terrestres geradas por queimadas, poeiras e emissões biológicas. A associação entre a composição do material dissolvido e/ou particulado presente nas águas dos rios possibilita a caracterização dos processos erosivos predominantes, mecânicos e/ou químicos (Mortatti \& Probst, 1998). A influência do substrato rochoso e da ação antrópica na composição química das águas superficiais foi observada por Bortoletto Jr. et al. (2002) nas águas da bacia do rio Corumbataí (SP). Os autores apontam que os íons $\mathrm{HCO}_{3}{ }^{-} \mathrm{Na}^{+}$e $\mathrm{SiO}_{2}$, os mais abundantes na carga dissolvida transportada fluvialmente, tem sua presença associada tanto a aportes geológicos, quanto à contribuição antropogênica. Segundo os autores, apesar da baixa qualidade de suas águas, o rio Corumbataí contribuía para o abastecimento das cidades de Rio Claro e Piracicaba, no Estado de São Paulo.

A importância para a gestão integrada de recursos hídricos de estudos que ampliem o conhecimento da composição química de águas superficiais em bacias hidrográficas, está inicialmente relacionada a avaliação da sua qualidade, bem como para identificar as relações existentes com as águas subterrâneas ou meteóricas, além de possibilitar a avaliação das taxas de denudação e reconhecimento de processos geoquímicos atuantes no interior da bacia hidrográfica (Brennan \& Lowenstein, 2002). Dessa forma, os estudos a respeito dessas questões ambientais voltadas à gestão integrada dos recursos hídricos, especialmente em áreas onde as águas superficiais apresentam pequeno impacto pela ação antrópica, se tornam cada vez mais urgentes.

0 presente estudo teve por objetivos à avaliação da qualidade da água, química e biológica, por meio da utilização do IQA (Índice de Qualidade da Água), bem como a utilização de técnicas hidrogeoquímicas, na compreensão dos principais processos geoquímicos responsáveis pela composição físico-química das águas superficiais da sub-bacia do Alto Jacaré Pepira. Localizada na porção central do estado de São Paulo, foi selecionada para este estudo devido a sua inserção em Área de Preservação Permanente (APA), a relativa complexidade do seu arcabouço geológico, que inclui uma importante área de recarga do Sistema Aquífero Guarani (SAG) e devido à importância econômica que os recursos hídricos representam especialmente para a cidade de Brotas (SP), por meio da exploração como atração turística. Apesar da pressão da ocupação urbana e da pressão exercida pelas 
atividades agrícolas desenvolvidas na área, programas de monitoramento da qualidade das águas superficiais, realizados pela CETESB (Companhia Ambiental do Estado de São Paulo), atestam a qualidade do recurso e a pequena influência da ação antrópica na sua composição química.

\section{2 Área, materiais e métodos}

\subsection{Localização da área de estudo}

A área de estudo, a sub-bacia do Alto Jacaré-Pepira, está localizada na porção central do Estado de São Paulo, situada a montante da bacia hidrográfica do Rio Tietê-Jacaré (BH-TJ), que se estende por $15.808 \mathrm{~km}^{2}$ (IPT, 2000) (Fig. 1).

A sub-bacia do Alto Jacaré-Pepira (SP) se estende por uma área de $1.411 \mathrm{~km}^{2}$, abrangendo os municípios de São Pedro, Torrinha, Brotas, Dourados, Dois Córregos, Ribeirão Bonito e Itirapina. A nascente principal do rio está localizada na Serra de Itaqueri, próxima à divisa dos municípios São Pedro, Itirapina e Brotas, a uma altitude aproximada de $960 \mathrm{~m}$. Em seu curso o Rio Jacaré-Pepira percorre aproximadamente $200 \mathrm{~km}$ até sua foz no Rio Tietê, situada no município de Ibitinga (SP), a uma cota aproximada de $400 \mathrm{~m}$ (IPT, 2000).

A CETESB vem monitorando desde 1978 a qualidade das águas superficiais na bacia do Rio Jacaré-Pepira, inicialmente com um ponto de amostragem (PPEP03500), até o ano de 2010, quando um segundo ponto de monitoramento foi implantado na sub-bacia (JPEP03600). De acordo com dados do Relatório de Qualidade das Águas Superficiais da CETESB (CETESB, 2014), estes pontos de monitoramento, localizados à jusante da sub-bacia, mostraram que as águas do Rio Jacaré-Pepira são de boa qualidade, baseando-se nos cálculos do Índice de Qualidade da Água (IQA), que de acordo com a resolução CONAMA n³57/2005 (CONAMA, 2005), se enquadram como rios de classe 2 (IPT, 2000).

A precipitação média anual entre os anos de 1972 e 1999 foi de $1509,7 \mathrm{~mm} / \mathrm{ano}^{-1}$, distribuida ao longo do ano em duas estações: uma chuvosa, entre os meses de dezembro a fevereiro, concentrando cerca de $50 \%$ de toda a precipitação anual, e uma estação mais seca, que se estende de junho a agosto, quando chove aproximadamente $5 \%$ do índice anual (SIGRH, 2005).

Geologicamente a sub-bacia do Rio Jacaré-Pepira encontra-se assentada predominantemente sobre unidades que constituem a sequência mesozoica da bacia Sedimentar do Paraná, repre- sentada pelos sedimentos clásticos-arenosos das formações Botucatu e Pirambóia e sobre as rochas ígneas basálticas da Formação Serra Geral, (IPT, 2000). Além dessas unidades, afloram rochas sedimentares pertencentes ao Grupo Bauru, sedimentos pertencentes à Formação Itaqueri (Cretáceo) e depósitos correlatos cenozoicos, situados na Serra de São Carlos, e pelos sedimentos aluvionares quaternários associados à rede de drenagem (IPT, 2000).

A sub-bacia do Alto Jacaré-Pepira está inserida em área de recarga do Sistema Aquífero Guarani, associada aos afloramentos das unidades geológicas que constituem essa importante unidade hidroestratigráfica do continente Sul Americano. Além dessa unidade são reconhecidos os seguintes aquíferos: Cenozoico, Sistema Aquífero Bauru e Aquífero Serra Geral (IPT, 2000).

\subsection{Métodos}

Com o objetivo de se avaliar a qualidade, e as concentrações iônicas das águas superficiais na sub-bacia do Alto Jacaré-Pepira, foram coletadas amostras de águas superficiais em dezessete pontos de amostragem, cuja distribuição pode ser vista na figura 1 . As coletas foram realizadas entre os dias 10 a 30 de julho de 2013.

Foi estabelecida uma malha regular de amostragem ao longo da sub-bacia, levando em consideração o arcabouço geológico e a distribuição da rede de drenagem da área. A sub-bacia foi dividida inicialmente em parte alta (pontos A1 a A5), média (pontos B1 a B6) e baixa (pontos C2 a C7), com o objetivo de facilitar a distribuição da malha de amostragem e organização das campanhas de coleta. Para tanto, foi realizado o cruzamento de mapas geológicos (DAEE/UNESP, 1980; Sachs, 1999), mapas de drenagem e folhas topográficas SF-23-Y -A e SF-22-Z-B, escala 1:250.000, disponíveis em: http://www.relevobr.cnpm.embrapa.br/ (Miranda, 2005) e imagens atuais da área de estudo acessadas no Google Earth, versão 2013.

As amostras foram coletadas diretamente nos cursos d'água, com o auxílio de uma garrafa Van Dorn. Em campo, no momento da coleta, foram medidos os seguintes parâmetros: temperatura do ar, temperatura da água, $\mathrm{pH}$, oxigênio dissolvido, condutividade elétrica e salinidade, utilizando uma sonda Multiparâmetros da marca YSI, modelo 556 MPS. Para determinação dos parâmetros constituintes do IQA (temperatura, $\mathrm{pH}$, oxigênio dissolvido, demanda bioquímica de oxigênio DBO, coliformes termotolerantes, nitrogênio total, fósforo total, sólidos totais e turbidez) duas alíquo- 


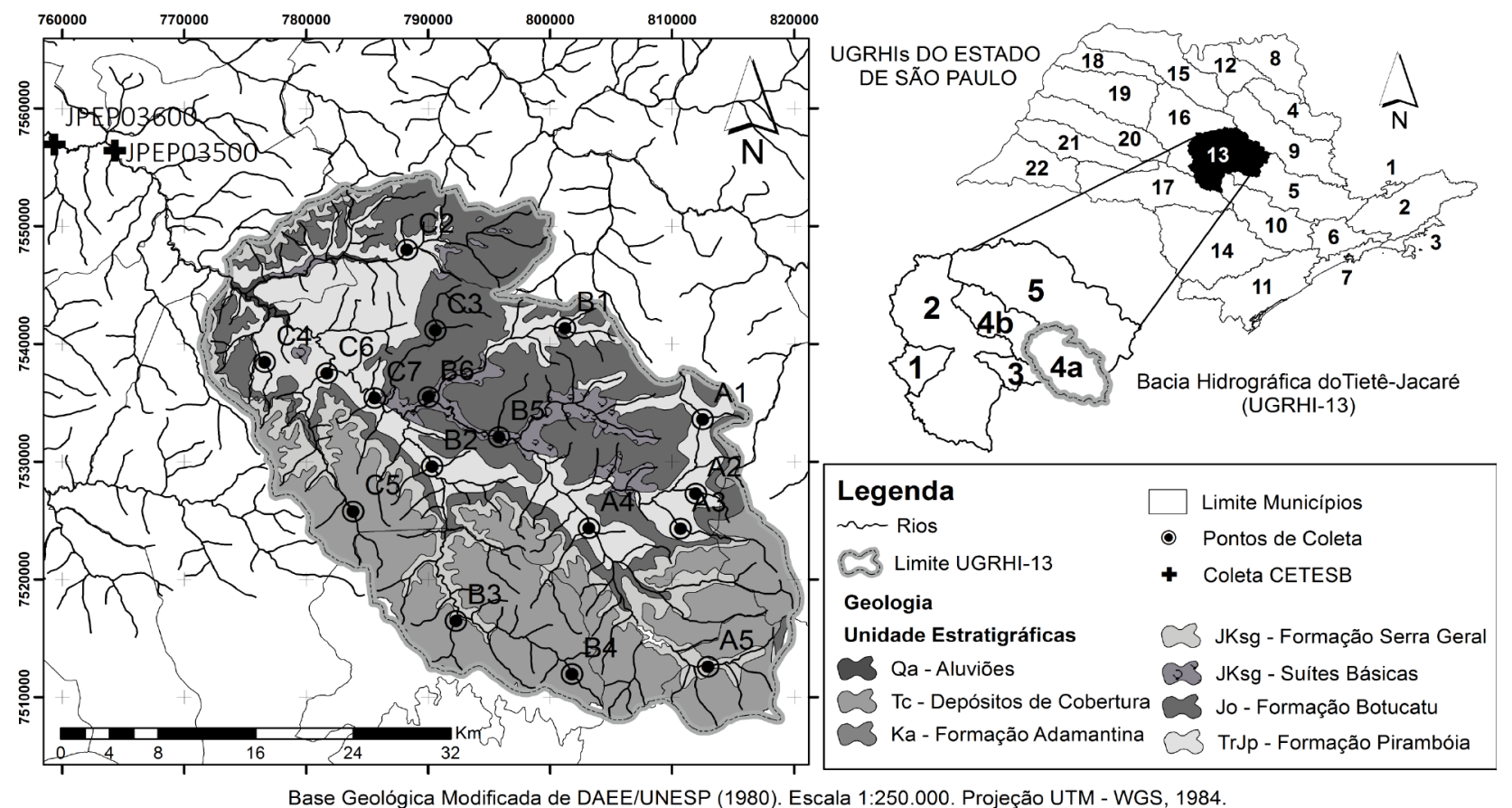

Figura 1. Mapa geológico simplificado da área de estudo indicando os pontos de amostragem, bem como a localização da sub-bacia do Alto Jacaré Pepira no estado de São Paulo e no contexto da Bacia Hidrográfica do Tietê-Jacaré (Unidade de Gerenciamento de Recursos Hídricos - UGRHI 13).

tas da amostra foram acondicionadas em frascos de polietileno de $1 \mathrm{~L}$. As amostras para análises microbiológicas foram coletadas em frascos de polietileno de $50 \mathrm{~mL}$, previamente esterilizados, além de duas aliquotas de $200 \mathrm{~mL}$ filtradas com filtro de acetato de celulose de $0,45 \mu \mathrm{m}$ para a determinação de cátions e ânions dissolvidos. A aliquota utilizada para a determinação de cátions foi preservada com ácido nítrico até $\mathrm{pH}$ inferior a 2 . Todas as amostras foram preservadas sob refirgeração até a chegada ao laboratório.

As determinações dos parâmetros físico-químicos, sejam sólidos totais dissolvidos (STD), sólidos suspensos totais (SST), demanda bioquímica de oxigênio (DBO), cor e turbidez; e microbiológicos (coliformes totais e Escherichia coli), foram realizadas nas dependências dos Laboratórios do CEA (Centro de Estudos Ambientais, UNESP, Rio Claro), enquanto a determinação de cátions $\left(\mathrm{Na}^{+}\right.$, $\left.\mathrm{K}^{+}, \mathrm{Ca}^{+}, \mathrm{Mg}^{2+}, \mathrm{Fe}_{\text {(total) }}, \mathrm{Sr}^{2}\right)$ e ânions $\left(\mathrm{HCO}_{3}{ }^{-}, \mathrm{CO}_{3}^{2-}\right.$, $\mathrm{Cl}, \mathrm{NO}_{3}{ }^{-}, \mathrm{SO}_{4}{ }^{2}$ ) foi realizada no Laboratório de Hidrogeologia e Hidroquímica do Departamento de Geologia Aplicada do IGCE/UNESP, Rio Claro, respectivamente por ICP-MS e Cromatografia de Íons. Os métodos analíticos empregados basearam-se no Standard Methods for the Examination of Water and Wastewater (AHA/AWWA/WEF, 1995).

Para a determinação do nitrogênio total (NN) foi utilizada a técnica da digestão ácida $\left(\mathrm{H}_{2} \mathrm{SO}_{4}\right.$ - 0,02N), pelo método da nesslerização e titulação, conforme metodologia proposta por Mackereth et al. (1978). A quantificação das concentrações de fósforo (P) foi realizada nas dependências do Laboratório de Hidrogeologia e Hidroquímica do Departamento de Geologia Aplicada do IGCE/UNESP, por espectofotometria. As amostras foram previamente preparadas, por meio do método de digestão em ácido sulfúrico $\left(\mathrm{H}_{2} \mathrm{SO}_{4}\right)$, sendo utilizado kit de testes da Merk, e a leitura realizada em espectrofotômetro da marca SPEKOL 1500.

A avaliação da qualidade da determinação de cátions e ânions foi feita por meio do cálculo do balanço de cargas $\left(\Delta_{\text {meq }}=100 \cdot\left(\sum_{\text {meq }}{ }^{+}-\sum_{\text {meq }}{ }^{-}\right) /\left(\sum_{\text {meq }}{ }^{+}+\right.\right.$ $\left.\sum_{\text {meq }}{ }^{-}\right)<10 \%$ ), considerando-se erros inferiores a $10 \%$ como satisfatórios. Para classificação dos tipos hidroquímicos os dados foram tratados e plotados em Diagramas de Piper (Piper, 1944), com a utilização do software Diagrames (Smiler, 2014).

\section{Resultados e discussões}

Nas tabelas 1 e 2 são apresentados os resultados analíticos dos parâmetros físico-químicos e microbiológicos das amostras coletadas na sub -bacia do Alto Jacaré-Pepira, assim como os valores máximos estabelecidos pela Resolução CONAMA $\mathrm{n}^{\circ} 357 / 2005$ para rios de classe 2 (CONAMA, 2005) (Tab. 1) e os valores de erro de balanço de massa (Tab. 2), que permitiu a validação dos resultados analíticos obtidos. 


\section{1 Índice de qualidade da água (IQA)}

O Índice de Qualidade da Água (IQA) foi criado em 1970 pelo National Sanitation Foundation (NSF), dos Estados Unidos da América, a partir de uma pesquisa de opinião realizada com especialistas em qualidade de águas. Para o cálculo do IQA, inicialmente foram propostos trinta e cinco parâmetros indicadores de qualidade de água, que foram reduzidos posteriormente para a composição do atual IQA, constituído por apenas nove parâmetros, a saber: temperatura, $\mathrm{pH}$, oxigênio dissolvido, demanda bioquímica de oxigênio (DBO), coliformes termotolerantes, nitrato, fosfato, sólidos totais e turbidez (CETESB, 2010).

No Brasil, a Companhia de Tecnologia de Saneamento Ambiental do Estado de São Paulo (CETESB), desde 1975, utiliza uma versão do IQA, adaptada da versão original do NSF. Nessa adequação, o parâmetro nitrato foi substituído por nitrogênio total, e o parâmetro fosfato total foi substituído por fósforo total. Atualmente, a CETESB utiliza outros índices específicos para cada uso, tais como o IAP, para abastecimento público, o IVA para proteção da vida aquática, entre outros.

A classificação adotada pela CETESB para o IQA considera pesos específicos para cada um dos nove parâmetros determinados, sendo o somatório dos pesos de todos os parâmetros igual a 1 , enquanto o IQA representa o produto das ponderações dos diversos parâmetros, e é dada pela fórmula (Equação 1) (CETESB, 2010):

$$
I Q A=\prod_{i=1}^{n} q_{i}^{w i}
$$

Onde:

IQA: Îndice de Qualidade das Águas, um número entre 0 e 100 ;

$\mathbf{q}_{\mathrm{i}}$ : qualidade do i-ésimo parâmetro, um número entre 0 e 100 , obtido da respectiva "curva média de variação de qualidade", em função de sua concentração ou medida;

$\mathbf{w}_{\mathrm{i}}$ : peso correspondente ao i-ésimo parâmetro, um número entre 0 e 1 , atribuído em função da sua importância para a conformação global de qualidade;

i: número do parâmetro, variando de 1 a 9 ( $\mathrm{n}=9$, ou seja, o número de parâmetros que compõem o IQA).

A partir do cálculo efetuado, pode-se determinar a qualidade das águas brutas e classificá-las numa escala de 0 a 100 , que indica o IQA. Os valores calculados variaram de 63 a 82, com os melhores índices observados nos pontos localizados a montante da bacia, e os índices menores a jusante (Fig. 2). De acordo com a classificação dos valores de IQA, adotada pela CETESB, apenas o ponto B3 se enquadrou na categoria "Ótima", apresentando valor de IQA de 82. Os demais pontos de amostragem se enquadraram na categoria "Boa", variando o IQA de 63 a 78 (Tab. 1). A redução da qualidade da água, traduzida por diminuição nos valores de IQA, estão associados a uma maior presença de coliformes termotolerantes (Escherichia coli), redução da concentração de oxigênio dissolvido (OD) e da demanda bioquímica de oxigênio (DBO), nos pontos de amostragem próximos as cidades de Brotas (B2, B5, B6 e C7), indicando uma alteração promovida pela ação antrópica, possivelmente associada ao lançamento de esgotos, enquanto os maiores valores, e consequentemente a melhor classificação, nas áreas das cabeçeiras de drenagem (montante da bacia), associados a menores bacias de contribuição e ausência de fontes de contaminação.

A jusante da área de estudo, a CETESB vem monitorando de maneira contínua dois pontos no Rio Jacaré Pepira (PPEP03500 e JPEP03600, respectivamente desde 2003 e 2010) (Fig.1). Os valores para o IQA nesses pontos variaram de 67 a 78, semelhantes aos valores médios observados nesse estudo (Fig. 3). Apesar da diminuição da qualidade da água nas proximidades da cidade de Brotas (SP) (Pontos B5 e B6), é possível se afirmar que a descarga de águas provenientes de sub-bacias preservadas, tanto na margem direita, quanto na margem esquerda do Rio Jacaré-Pepira contribui para a melhoria dos índices de IQA a jusante, nos pontos monitorados pela CETESB.

\subsection{Parâmetros físico-químicos das águas superfi- ciais}

O cálculo do balanço iônico, uma das maneiras de se avaliar a qualidade das análises químicas de águas, indica que das 17 amostras analisadas, nenhuma apresentou valores superiores aos limites estabelecidos de $<10 \%$, de acordo com a metodologia proposta por Custódio \& Llamas (2001), validando os resultados analíticos obtidos, e possibilitando uma avaliação hidroquímica confiável. Os erros variaram de 2,78 \% a 7,39 \%, com valores médios de $+5,70 \%$, indicando prevalência das concentrações de cátions sobre os ânions nas determinações realizadas (Tab. 2).

As concentrações dos sólidos totais em suspensão (STS) apresentaram variação de 1,40 mg $\mathrm{L}^{-1}$ a $11,00 \mathrm{mg} \mathrm{L}^{-1}$, com média de 4,49 $\mathrm{mg} \mathrm{L}^{-1}$. Os valores de STS e TDS (totais de sólidos dissolvidos) tendem a aumentar em direção a jusante e ter boa 


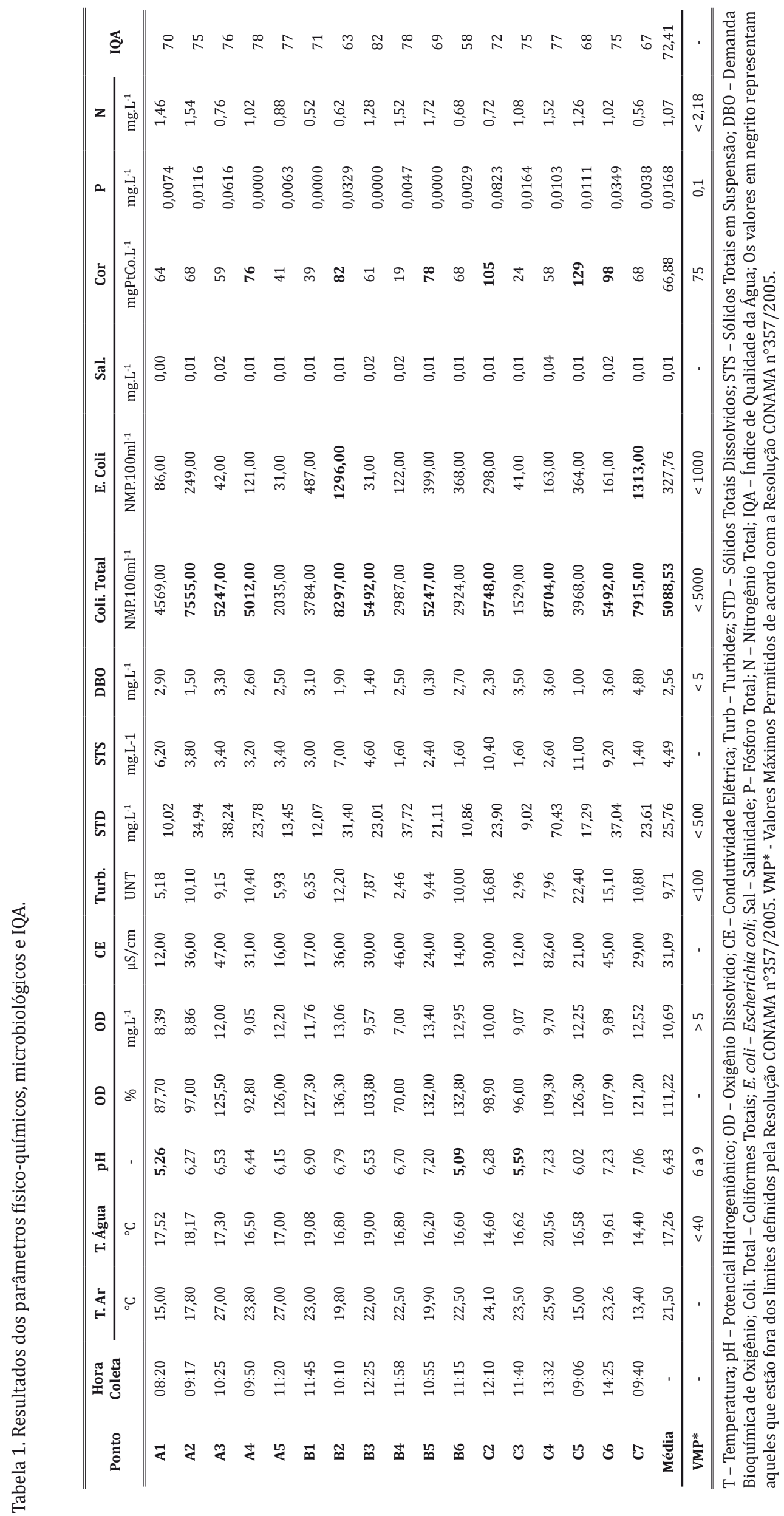




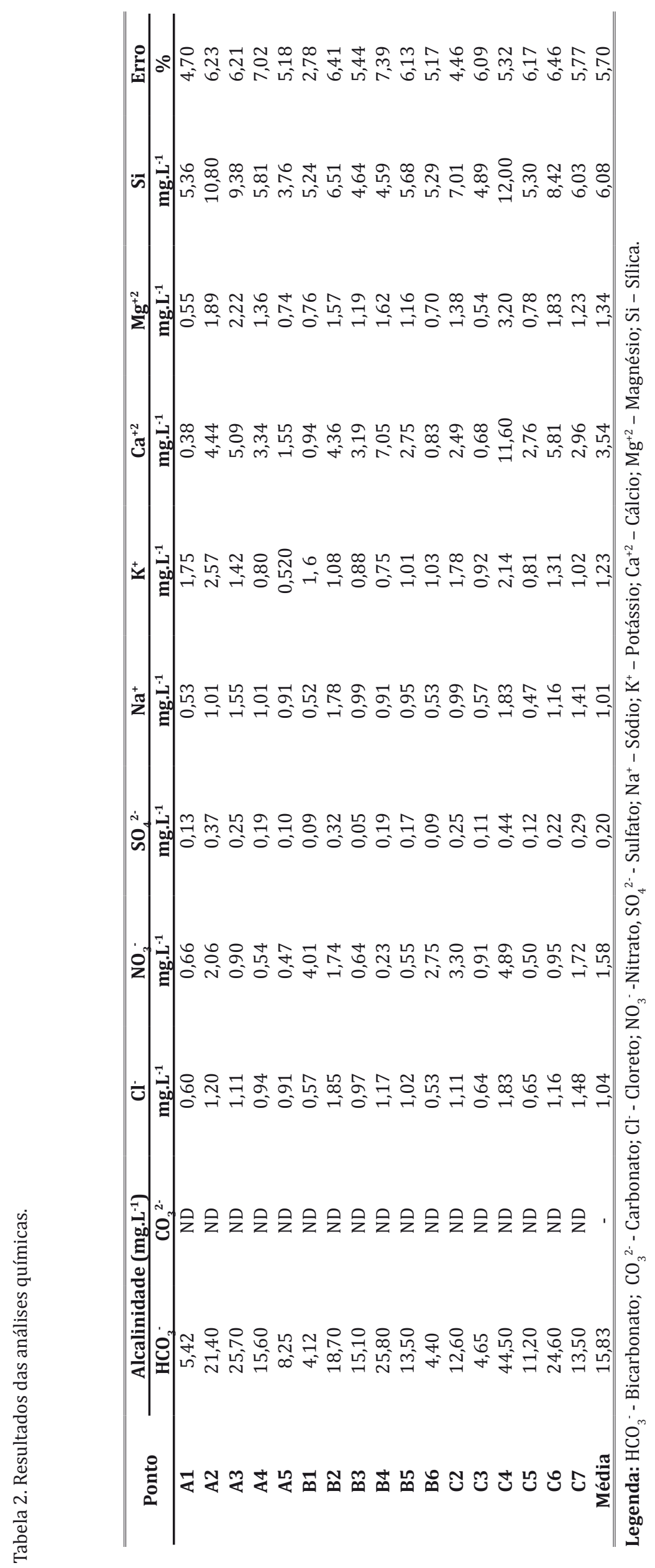




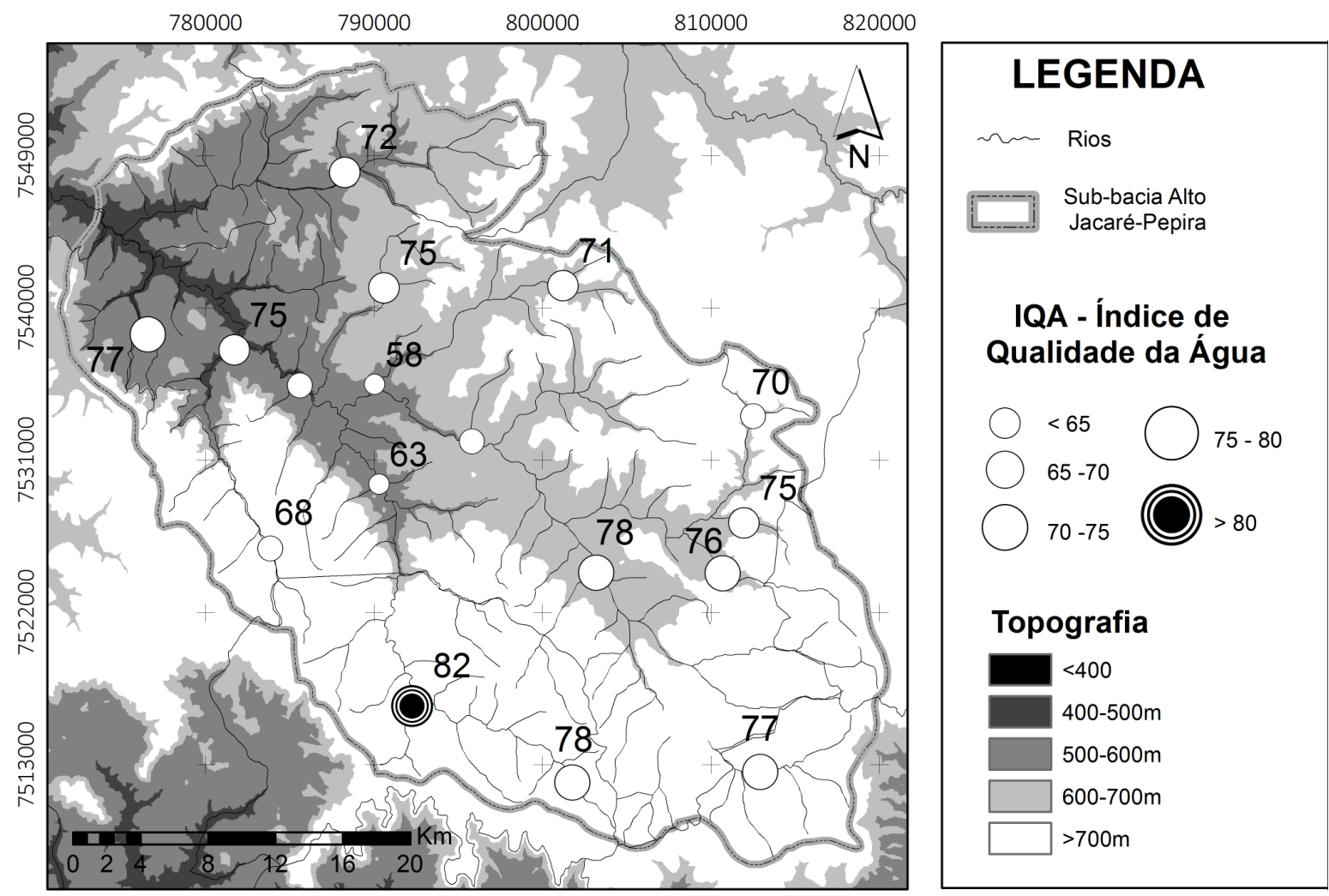

Folhas Topográfica SF-22-ZB (Bauru) e ZF-23-YA (Campinas). Modificado de Miranda (2005). Escala 1:250.00. Projeção UTM-WGS, 1984.

Figura 2. Mapa de distribuição espacial do IQA na sub-bacia do Alto Jacaré-Pepira.

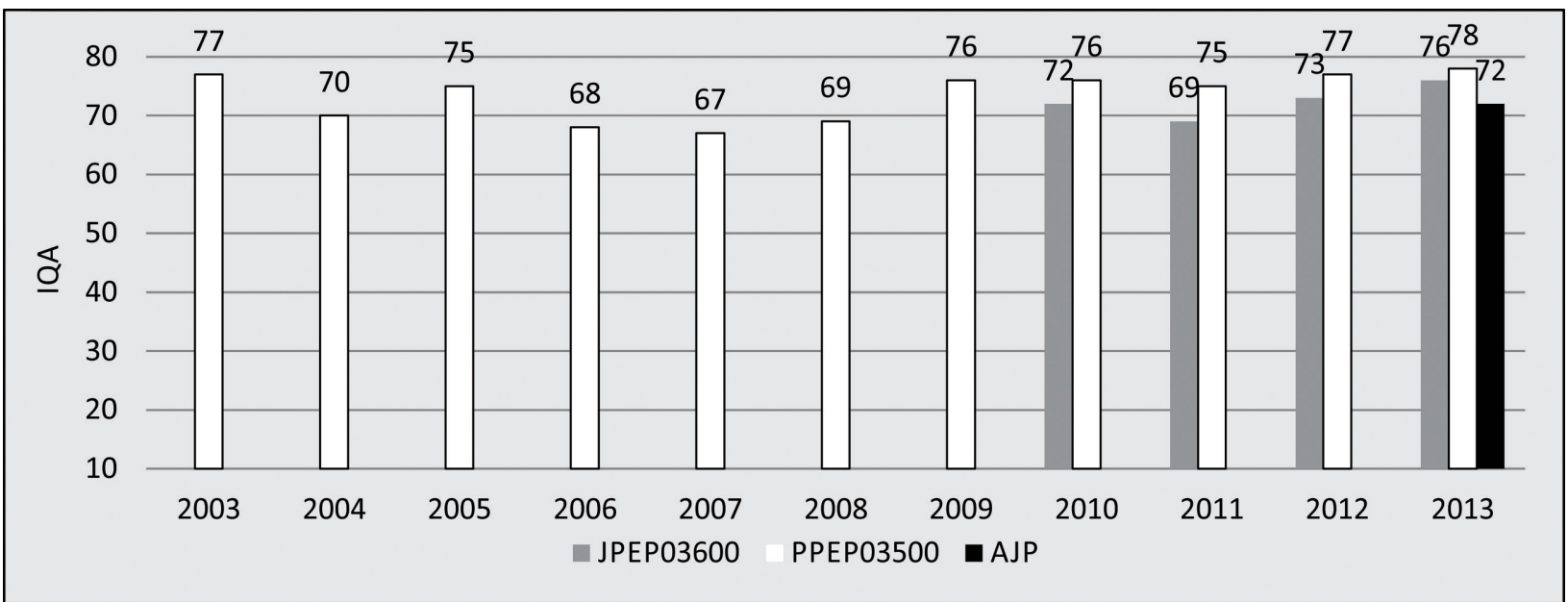

Figura 3. Série temporal dos resultados do IQA do monitoramento da CETESB (PPEP03500 e JPEP03600) e resultados do IQA da sub-bacia do Alto Jacaré-Pepira (AJP). Fonte: CETESB (2014).

correlação com os valores de CE, que revela a presença de íons dissolvidos na água e capacidade de conduzir eletricidade.

A condutividade elétrica (CE) das águas superficiais na área de estudos apresenta valor médio de $31,09 \mu \mathrm{S} \mathrm{cm}^{-1}$, variando de $12,0 \mu \mathrm{S} \mathrm{cm}^{-1} \mathrm{a}$ $82,6 \mu \mathrm{Sm}^{-1}$. Os maiores valores de CE foram observados nos pontos situados a jusante da bacia, localizados em áreas de afloramento da Formação Pirambóia, assim como em alguns pontos nas partes altas da bacia (A2 e A3), localizadas em áreas de maior declive. As menores condutividades estão relacionadas às nascentes situadas nas porções mais elevadas da bacia de drenagem, indicando uma menor mineralização nessas áreas, devido ao pouco tempo de contato entre água e rocha.

As concentrações de sólidos totais dissolvidos (STD) para cada amostra foram determinadas a partir da somatória total da concentração dos íons analisados, e o valor médio para o STD foi de $25,76 \mathrm{mg} \mathrm{L}^{-1}$, variando de 9,02 $\mathrm{mg} \mathrm{L}^{-1}$ a 70,43 mg $\mathrm{L}^{-1}$. Como esperado o STD apresenta excelente cor- 
relação com a condutividade elétrica (Fig. 4).

Os valores de $\mathrm{pH}$ varian entre 5,09 e 7,23, com média de 6,43. Os valores de $\mathrm{pH}$ indicam o estado de equilíbrio das reações aquosas, sendo que, grande parte da sua estabilização em águas naturais é controlada pela reação de dissolução do $\mathrm{CO}_{2}$ (Hem, 1985).

Os pontos amostrados que se localizam sobre as formações Serra Geral (Suítes Básicas) e Pirambóia apresentaram pH próximo a neutralidade, enquanto os pontos localizados sobre a Formação Botucatu apresentam pH levemente ácido. Essa variação dos valores do $\mathrm{pH}$ é devida principalmente, a assembleia mineralógica distinta das unidades estratigráficas, que leva a consumo distinto de $\mathrm{CO}_{2}$ durante o processo de intemperismo dos minerais silicáticos.

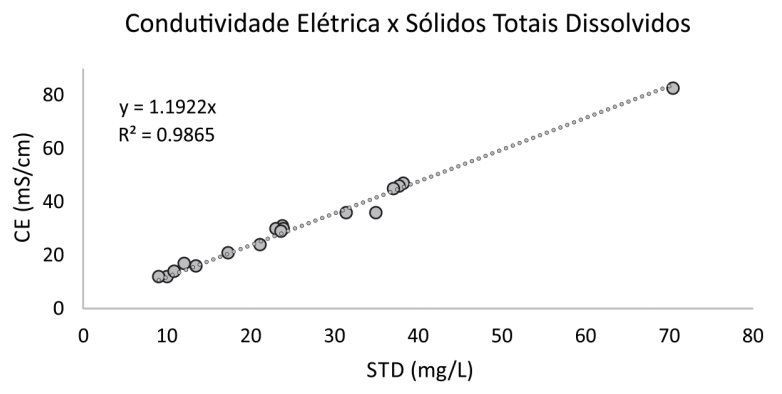

Figura 4. Correlação entre condutividade elétrica (CE) e sólidos totais dissolvidos (STD).

\subsection{Classificação hidrogeoquímica}

A composição química das águas superficiais na sub-bacia do Rio Jacaré-Pepira foi avaliada com base nas concentrações dos principais cátions e ânions dissolvidos, a saber: $\mathrm{Ca}^{2+}, \mathrm{Na}^{+}, \mathrm{Mg}^{2+}, \mathrm{K}^{+}$, $\mathrm{HCO}_{3} ; \mathrm{Cl}^{-}, \mathrm{SO}_{4}{ }^{2-}$ e $\mathrm{NO}_{3}$.

Empregando-se o Diagrama de Piper (Piper, 1944), é possível classificar as águas superficiais da sub-bacia do Alto Jacaré-Pepira, como bicarbonatadas cálcio-magnesianas, indicando a predominância do $\mathrm{HCO}_{3}^{-}$sobre os íons $\mathrm{Cl}^{-}$e $\mathrm{SO}_{4}^{-2}$, enquanto o $\mathrm{Ca}^{2+}$ e o $\mathrm{Mg}^{+}$são predominantes entre os cátions (Fig. 5), o que pode caracterizar a natureza mais "dura" de algumas amostras, associadas à hidrólise de silicatos em presença de dióxido de carbono (Custodio \& Llamas, 2001).

\subsection{Avaliação hidrogeoquímica}

As relações entre os íons dissolvidos presentes na água representam normalmente as interações ocorridas entre a água e o substrato rochoso, indicando a ação de fenômenos modificadores, ou uma característica específica da água considerada. Para distinção da água segundo sua composição química, são necessárias análises dos principais cátions e ânions e comparações das relações entre eles (Custódio \& Llamas, 2001).

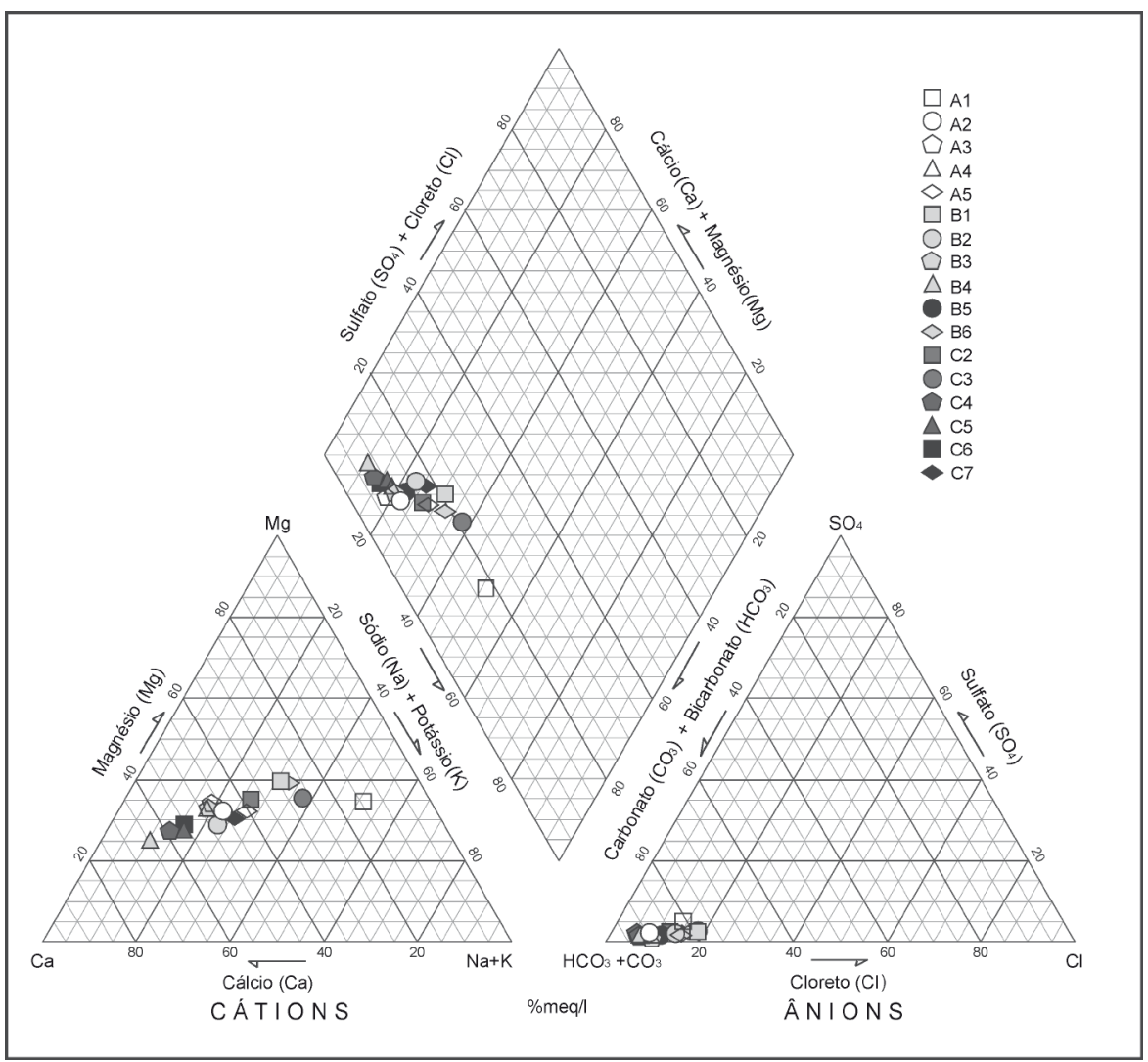

Figura 5. Classificação das águas superficiais de acordo com o Diagrama de Piper (Piper, 1944). 
As concentrações de $\mathrm{Ca}^{2+}$ nas águas superficiais da sub-bacia do Alto Jacaré Pepira, variaram de $0,38 \mathrm{mg} \mathrm{L}^{-1}$ a $11,60 \mathrm{mg} \mathrm{L}^{-1}$, com média de 3,54 $\mathrm{mg} \mathrm{L}^{-1}$. Segundo Custódio \& Llamas (2001), este elemento pode precipitar com facilidade e é muito afetado por trocas iônicas. Provém da dissolução de calcitas, dolomitas, anidrita, em rochas calcárias, sendo o plagioclásio e a apatita as maiores fontes de cálcio presentes nas rochas ígneas e sedimentares. 0 ataque aos feldspatos e aos outros silicatos cálcicos também contribui para a acumulação deste cátion.

As maiores concentrações de $\mathrm{Ca}^{2+}$ são observadas nos pontos situados na zona de afloramentos dos sedimentos da Formação Pirambóia, localizados nas porções mais baixas da sub-bacia do Alto Jacaré Pepira, com exceção do ponto B4, localizado sobre os Depósitos de Cobertura (Fig. 6).

Por ser o cátion mais abundante nas águas superficiais da sub-bacia, é esperada uma boa correlação entre a condutividade elétrica e as concentrações de $\mathrm{Ca}^{2+}$ das águas superficiais $(\mathrm{R}=0,96)$ (Fig. 7). Sua origem nas águas superficiais está associada a processos intempéricos, como a dissolução dos plagioclásios e de minerais presentes na cimentação dos arenitos, além de minerais secundários presentes nos basaltos, como a calcita, de acordo com as reações abaixo:

$$
\begin{aligned}
& \underset{\text { Anortita }}{\mathrm{CaAl}_{2} \mathrm{Si}_{2} \mathrm{O}_{8}+2 \mathrm{CO}_{2}}+\underset{2 \mathrm{H}_{2} \mathrm{O}}{\operatorname{Cal}} \rightarrow \underset{2}{\mathrm{Al}_{2} \mathrm{Si}_{2} \mathrm{O}_{5}(\mathrm{OH})_{4}}+\mathrm{Ca}^{2+}+2 \mathrm{HCO}_{3}{ }^{-} \\
& \mathrm{CaCO}_{3}+\mathrm{H}_{2} \mathrm{O}+\mathrm{CO}_{2} \rightarrow \mathrm{Ca}^{2+}+2 \mathrm{HCO}_{3} \\
& \text { Calcita }
\end{aligned}
$$

A alcalinidade, medida como $\mathrm{HCO}_{3}$; variou entre 4,12 $\mathrm{mg} \mathrm{L}^{-1}$ a 44,50 $\mathrm{mg} \mathrm{L}^{-1}$, com concentração média de $15,83 \mathrm{mg} \mathrm{L}^{-1}$. Conforme observado no diagrama de Piper (Fig. 5), o bicarbonato é o ânion dissolvido mais abundante nas águas da sub-bacia do Rio Jacaré-Pepira, que pode ser resultado da combinação da dissolução de dióxido de carbono $\left(\mathrm{CO}_{2}\right)$ atmosférico ou do solo, pelas águas superficiais e subterrâneas, associado à dissolução intempérica de rochas e minerais (silicatos e carbonatos) de acordo com as reações das equações 2 e 3 , apresentadas anteriormente (Fig. 8).

Observa-se um aumento das concentrações de $\mathrm{HCO}_{3}^{-}$nas águas superficiais na sub-bacia do Alto Jacaré Pepira em função do aumento da condutividade elétrica $(\mathrm{R}=0,98)$ (Fig. 9). A significativa correlação entre os parâmetros pode estar relacionada com a dissolução dos plagioclásios, presentes nos arenitos e nos basaltos, além de minerais secundários do basalto, como a calcita, via introdução de $\mathrm{CO}_{2}$ atmosférico (equações 2 e 3).

As concentrações de $\mathrm{Ca}^{2+}$ aumentam com as de $\mathrm{HCO}_{3}^{-}$, apresentando uma boa correlação $(R=0,98)$. Esse comportamento conjunto das concentrações desses compostos é observado em todos os pontos de amostragem, independentemente do contexto geológico em que as amostras foram coletadas na sub-bacia do Alto Jacaré Pepira (Fig. 10).

As concentrações de $\mathrm{NO}_{3}{ }^{-}$variaram de 0,23 $\mathrm{mg} \mathrm{L}^{-1}$ a 4,89 $\mathrm{mg} \mathrm{L}^{-1}$, com média de $1,58 \mathrm{mg} \mathrm{L}^{-1}$, enquanto as concentrações de $\mathrm{Cl}^{-}$variaram de 0,53 $\mathrm{mg} \mathrm{L}^{-1}$ a $1,85 \mathrm{mg} \mathrm{L}^{-1}$, com média de $1,06 \mathrm{mg} \mathrm{L}^{-1}$.

A relação entre as concentrações de nitrato e o aumento da contribuição do escoamento das águas na bacia ocorre, de maneira geral, no sentido de montante para a jusante. Alguns pontos de amostragem (A2, B1 e C4) localizados nas porções mais elevadas da área de estudo, apresentam altas concentrações de nitrato, fato que pode estar associado a possíveis fontes de contaminação antrópica pontuais e/ou difusas associadas a atividade agrícola desenvolvida no local, como a utilização de adubos, a disposição inadequada de resíduos animais, dentre outros.

Os pontos com as maiores concentrações de $\mathrm{Cl}^{-}$foram B2, $\mathrm{C} 4$ e $\mathrm{C} 7$, respectivamente, indicando que a entrada desse íon nas águas da sub-bacia do Alto Jacaré Pepira está associada a processo de dissolução de cloreto, e não as fontes pontuais de contaminação antrópica, observadas a partir da análise das concentrações de nitrato.

A partir da composição das águas dos rios foi possível estabelecer uma relação entre as razões iônicas e os tipos de rochas mais representativas desta sub-bacia hidrográfica, assim como Gaillardet et al. (1999) avaliaram nos principais rios do mundo (rios Amazonas, Reno, Sena, Níger, entre outros). Utilizando as razões $\mathrm{rHCO}_{3}-/ \mathrm{rNa}^{+}$versus $\mathrm{rCa}^{2+} / \mathrm{rNa}^{+}$e $\mathrm{rMg}^{2+} / \mathrm{rNa}^{+}$versus $\mathrm{rCa}^{2+} / \mathrm{rNa}^{+}$, o estudo possibilitou avaliar a litologia predominante na drenagem dos rios (carbonatos, silicatos ou evaporitos). Com base nestas relações, as razões calculadas para as águas da sub-bacia do Alto Jacaré-Pepira foram comparadas, indicando o predomínio de carbonatos e silicatos na bacia (Tab. 3).

A razão $\mathrm{rHCO}_{3}-/ \mathrm{rNa}^{+}$apresenta valores que variam de 3,04 a 10,87, com média de 5,79. Todos os pontos de amostragem apresentaram razão maior que 1 , mostrando o predomínio da dissolução de rochas e minerais silicáticos bem como de carbonatos, presentes como cimento nos arenitos das formações Botucatu e Pirambóia.

A razão $\mathrm{rCa}^{2+} \mathrm{rNa}^{+}$na área de estudo variou entre 0,82 a 8,91 , com média de 3,80 , indicando uma grande variação nas concentrações desses elementos nas amostras coletadas, porém de um 
modo geral, as amostras apresentaram predomínio de $\mathrm{Ca}^{2+}$ em suas concentrações (Fig. 11).

A razão $\mathrm{rMg}^{2+} / \mathrm{Na}^{+}$apresenta valores que variam de 1,56 a 3,59, e valor médio de 2,54 . Todos os pontos de amostragem, em ambas as campanhas, apresentaram razão maior que 1 , indicando a influência de rochas ricas em silicatos magnesianos e carbonato de cálcio, proveniente dos valores também acima da razão entre $\mathrm{rCa}^{2+} / \mathrm{rNa}^{+}$, já discutida anteriormente (Fig. 12).

A avaliação hidrogeoquímica das amostras apontou que as reações que fornecem as características químicas às águas estão associadas aos minerais presentes nas rochas basálticas, principalmente plagioclásios e minerais magnesianos, presentes nas rochas ígneas da Formação Serra

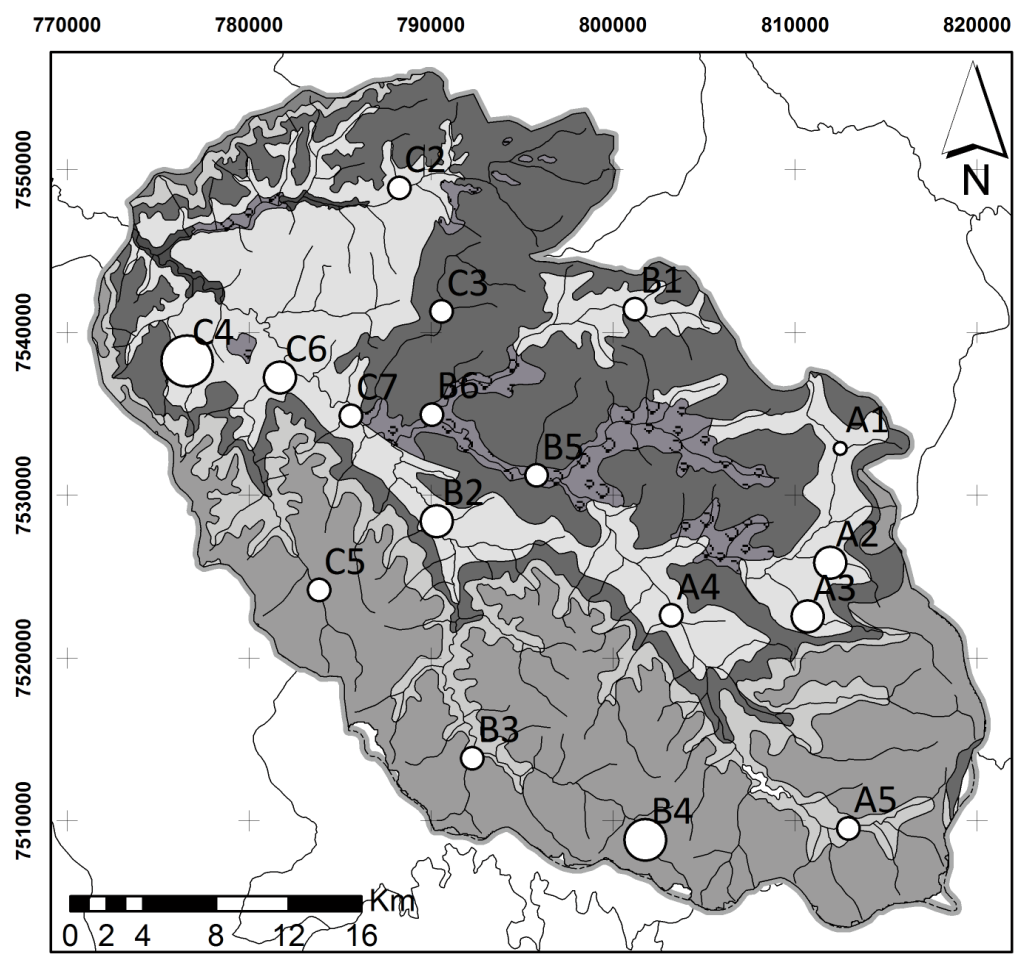

\section{Legenda}

Geologia

Unidade Estratigráficas

Qa - Aluviões

Tc - Depósitos de Cobertura

Ka - Formação Adamantina

J JKsg - Formação Serra Geral

JKsg - Suítes Básicas

Jo - Formação Botucatu

TrJp - Formação Pirambóia

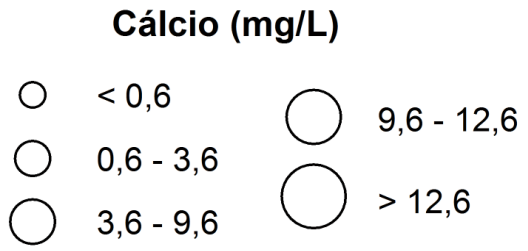

Base Geológica Modificada da DAEE/UNESP (1980). Mapa Geológico do Estado de São Paulo. Escala 1:250.000

Figura 6. Mapa de distribuição espacial da concentração de $\mathrm{Ca}^{2+}$.

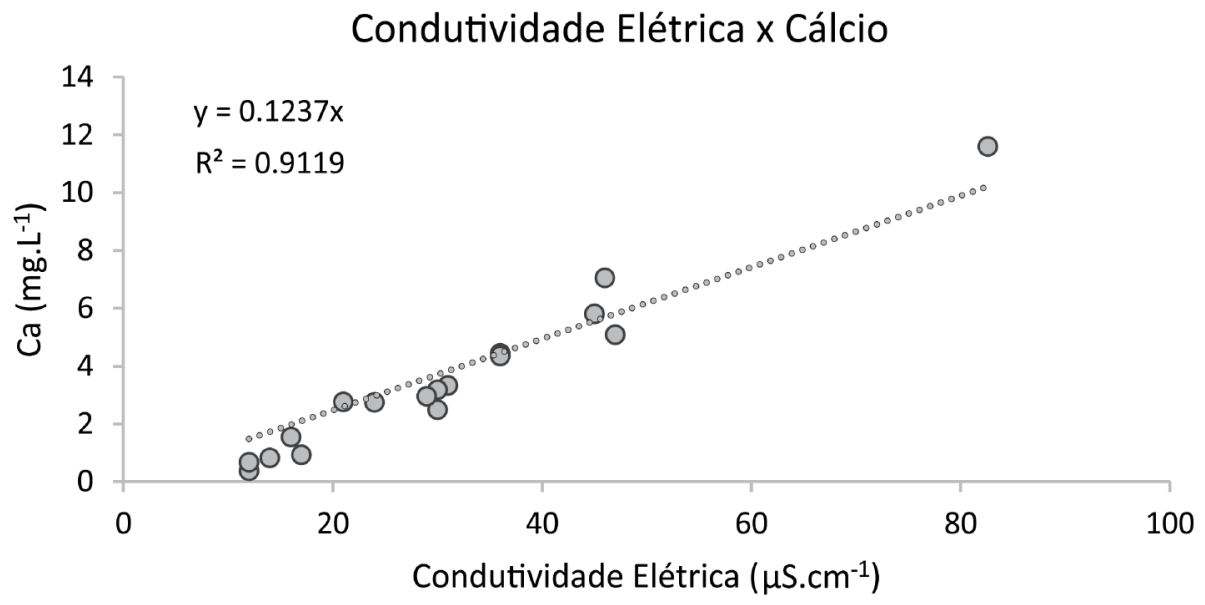

Figura 7. Correlação entre a condutividade elétrica (CE) e as concentrações de $\mathrm{Ca}^{2+}$ 
Geral e nos carbonatos dos arenitos da Formação de contato entre água-rocha, temperatura e da Botucatu e Pirambóia. Entretanto, as reações quí- presença de $\mathrm{CO}_{2}$.

micas de alteração mineral dependem do tempo

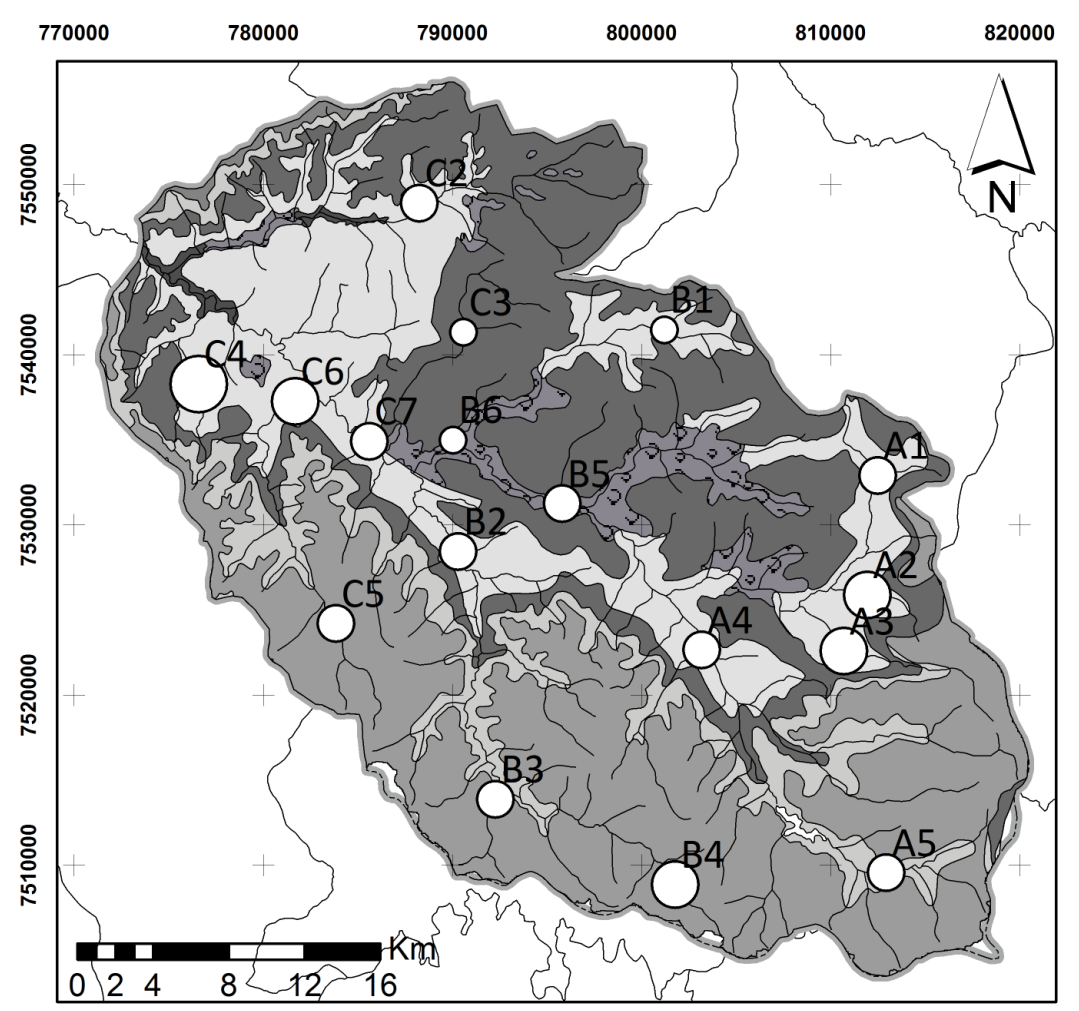

Legenda

\section{Geologia}

Unidade Estratigráficas

Qa - Aluviões

$\square$ Tc - Depósitos de Cobertura

Ka - Formação Adamantina

$\square$ JKsg - Formação Serra Geral

$[5] \mathrm{JKsg}$ - Suites Básicas

Jo - Formação Botucatu

TrJp - Formação Pirambóia

Alcalinidade (mg/L)

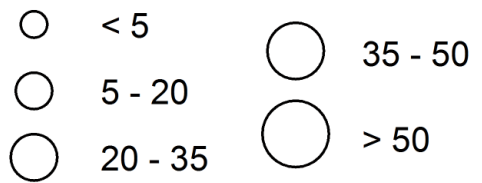

Base Geológica Modificada da DAEE/UNESP (1980) Mapa Geológico do Estado de São Paulo. Escala 1:250.000

Figura 8. Mapa de distribuição espacial das concentrações de $\mathrm{HCO}_{3}$ :

\section{Condutividade Elétrica x Alcalinidade}

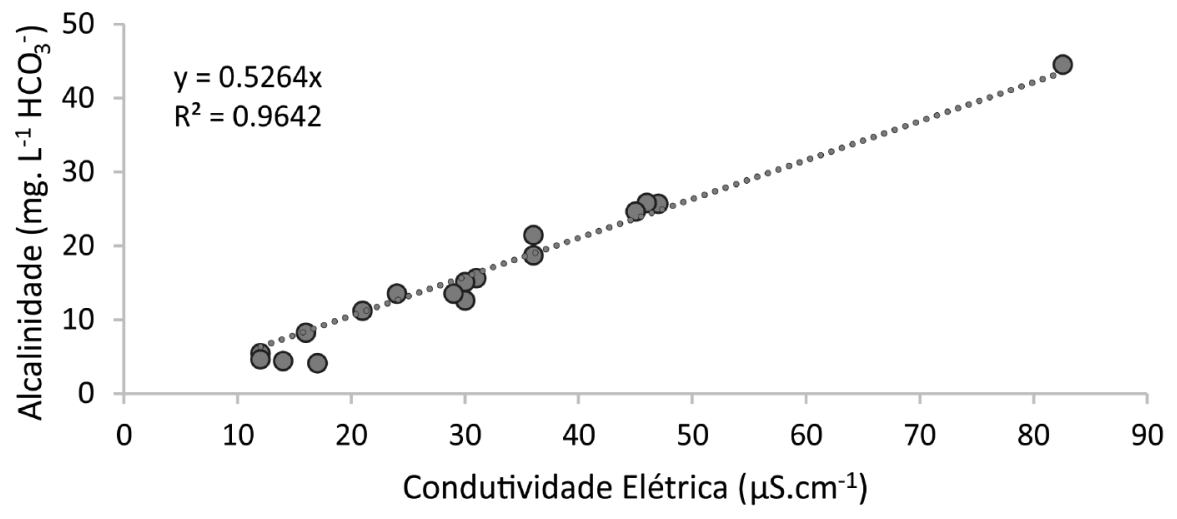

Figura 9. Correlação entre condutividade elétrica (CE) e as concentrações de $\mathrm{HCO}_{3}$ : 


\section{Cálcio x Alcalinidade}

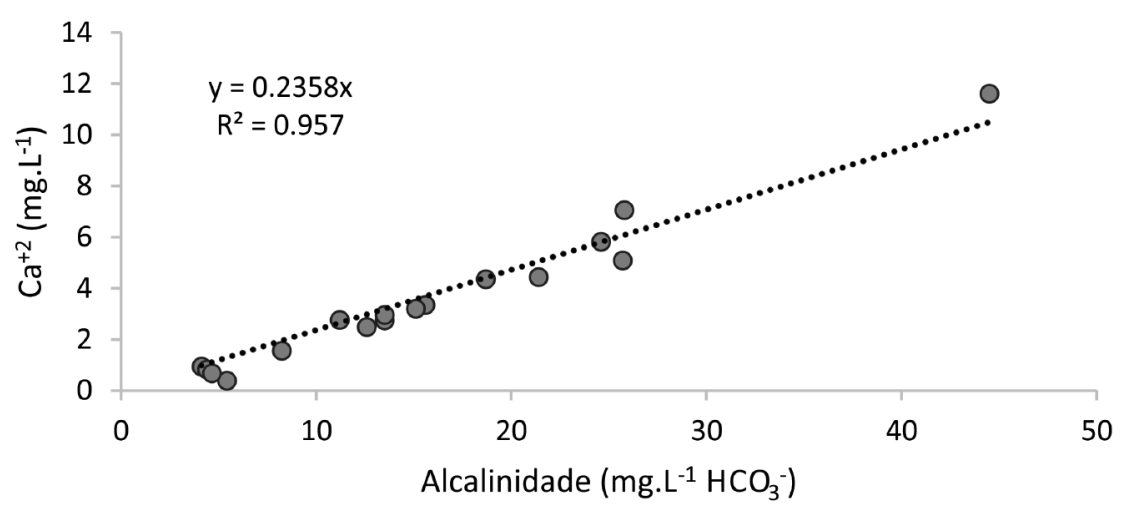

Figura 10. Correlação entre as concentrações de $\mathrm{Ca}^{+2}$ e $\mathrm{HCO}_{3}$ :

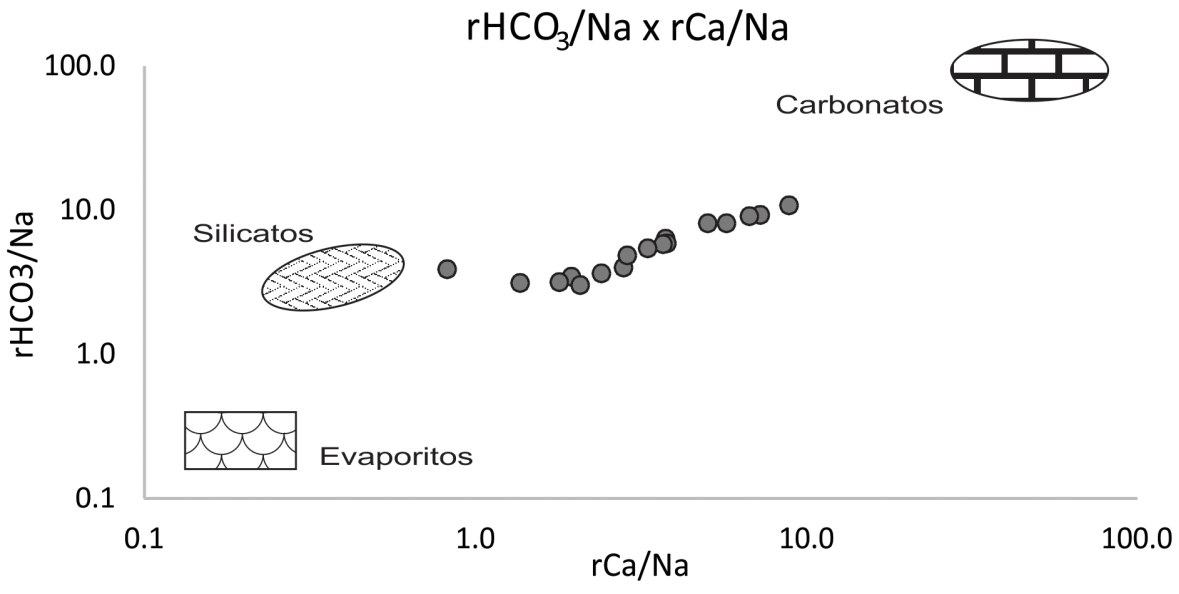

Figura 11. Gráfico de correlação das razões $\mathrm{rHCO}_{3}{ }^{-} / \mathrm{Na}^{+}$versus $\mathrm{rCa}^{+2} / \mathrm{Na}^{+}$, indicando a principal fonte dos íons dissolvidos nas águas superficiais da sub-bacia do Alto Jacaré Pepira (modificado de Galliardet et al., 1999).

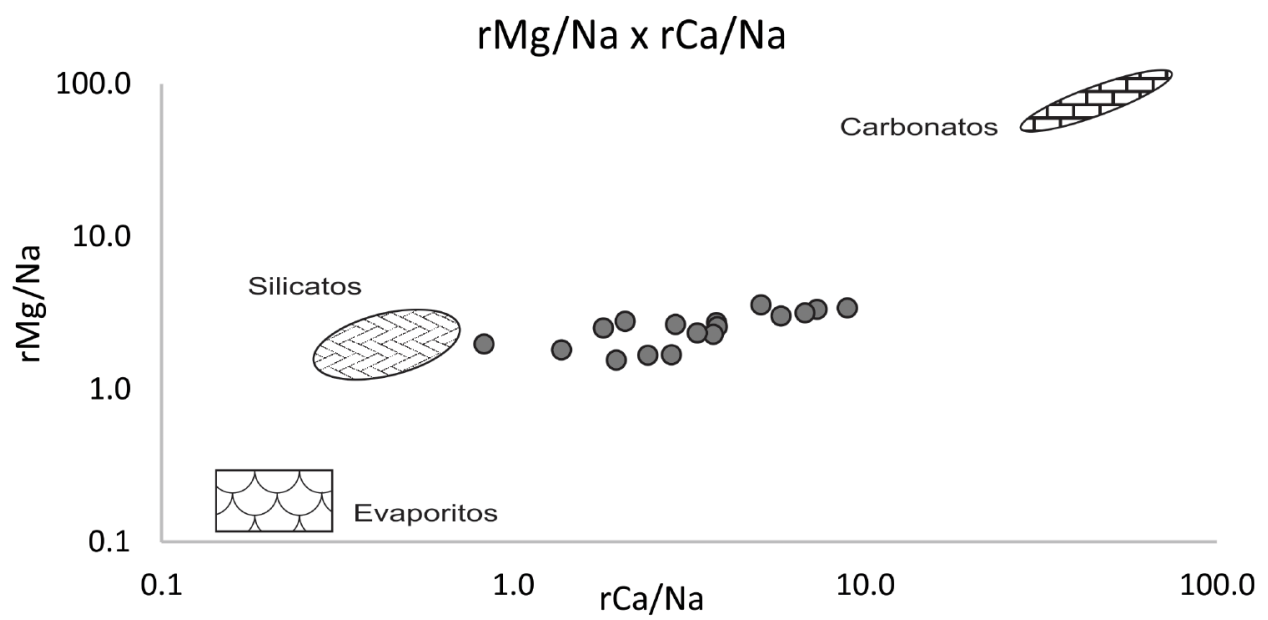

Figura 12. Gráfico de correlação das razões $\mathrm{rMg}^{+} / \mathrm{Ca}^{2+} / \mathrm{rCa}^{2+} / \mathrm{Na}^{+}$, indicando a principal fonte dos íons dissolvidos nas águas superficiais da sub-bacia do Alto Jacaré Pepira (modificado de Galliardet et al., 1999). 


\section{Conclusões}

Ao longo do presente estudo foram avaliadas as propriedades físico-químicas e microbiológicas, as características hidrogeoquímicas bem como a qualidade das águas da sub-bacia do Alto Jacaré-Pepira. Os resultados do IQA aferidos mostraram que as águas da sub-bacia do Alto Jacaré-Pepira são predominantemente de boa qualidade, entretanto, a qualidade das águas nos pontos coletados no entorno da cidade de Brotas (SP) apresentaram IQA inferior aos pontos localizados na cabeceira da bacia. 0 resultado do IQA dos dois pontos monitorados pela CETESB (2014), são semelhantes aos discutidos neste estudo, e também indicam que o aporte de águas "limpas" aumenta consideravelmente o valor do IQA.

Alguns parâmetros físico-químicos e microbiológicos estiveram em desacordo com a Resolução CONAMA n³57/2005 (CONAMA, 2005) para rios de classe 2, a saber: $\mathrm{pH}$, coliformes totais, coliformes termotolerantes (Escherichia coli) e cor. A possível causa pode estar relacionada com a ausência de chuva no período, que acarretou na diminuição do aporte de partículas do solo para os cursos d'água, assim como a vazão dos rios, diminuindo a dissolução das partículas.

Os valores de condutividade elétrica oscilaram significativamente de um ponto a outro, entretanto, os maiores valores foram observados nos pontos situados a jusante da bacia, localizados em áreas de afloramento da Formação Pirambóia, assim como em alguns pontos nas partes altas da bacia, localizadas em áreas de maior declive. Em contrapartida, os menores valores de condutividade elétrica estão relacionados com as nascentes situadas nas porções mais elevadas da bacia de drenagem, indicando uma menor mineralização nessas áreas, devido ao pouco tempo de contato entre água/rocha.

A caracterização hidrogeoquímica das águas superficiais da área de estudo mostrou que, em relação aos cátions dissolvidos, há o predomínio de

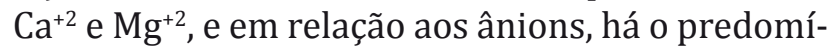
nio de $\mathrm{HCO}_{3}$. As águas analisadas em sua maioria são bicabornatadas-cálcicas ou magnesianas.

Os resultados das análises químicas das águas superficiais apresentaram a seguinte ordenação dos teores iônicos principais médios para a sub-bacia do Alto Jacaré-Pepira: $\mathrm{Ca}^{2+}>\mathrm{Mg}^{2+}>\mathrm{K}^{+}>\mathrm{Na}^{+}$ (cátions); $\mathrm{HCO}_{3}{ }^{-}>\mathrm{Cl}^{-}>\mathrm{NO}_{3}->\mathrm{SO}_{4}{ }^{2-}$ (ânions). A presença de bicarbonato como ânion principal, e de cálcio e magnésio como cátions predominantes, é compatível com o intemperismo de rochas basálticas e areníticas presentes na área de estudo.
Os aspectos relacionados à geoquímica encontrados nas águas, indicam que as águas superficiais da sub-bacia do Alto Jacaré-Pepira (SP), apresentam características similares às descritas para as unidades geológicas onde cada ponto de amostragem se encontra, ou seja, a possibilidade da recarga dos corpos d'água da sub-bacia ocorrerem preferencialmente através das águas subterrâneas, que manteriam o fluxo de base nessa rede de drenagem. Eventos de chuva ocasionariam o aumento instantâneo das vazões nos rios.

As águas da sub-bacia possuem, de modo geral, baixos valores de condutividade elétrica, associados com baixos valores de turbidez, sólidos totais em suspensão (STS) e sólidos totais dissolvidos (STD).

A ocorrência difusa de fontes de contaminação de cloreto e nitrato não interferiu na qualidade global das águas da sub-bacia, indicando que a introdução destes compostos na sub-bacia não acarretou a salinização das mesmas.

Agradecimentos - Os autores agradecem a Fundação de Amparo a Pesquisa do Estado de São Paulo (FAPESP), pelo apoio financeiro para a realização do presente projeto (Processo FAPESP 2012/00241-5), ao Conselho Nacional de Desenvolvimento Científico e Tecnológico - CNPq pela concessão de bolsa de estudos ao primeiro autor (Processo no 165533/2013-7), ao editor da revista pela revisão cuidadosa durante o processo editorial, bem como aos dois revisores anônimos, que com suas sugestões e comentários, colaboraram para a melhoria do manuscrito original.

\section{Referências}

AHA/AWWA/WEF. American Public Health Association/American Water Works Association/Water Environment Federation. 1995. Standard methods for the Examination of Water and Wastewater. 19. ed. Washington, American Public Health Association, 1472p.

Bortoletto Jr., M.J., Mortatti, J. \& Probst J.L. 2002. Erosão química na Bacia Hidrográfica do Rio Corumbataí (SP). Geochimica Brasiliensis, 16(1): 99-111.

ANA. Agência Nacional das Águas. 2005. Panorama da Qualidade das Águas Superficiais no Brasil. Brasília, Caderno de Recursos Hídricos, A Agência, 64p.

Brasil. 2011. Ministério da Saúde. Portaria no 2914 de 12 de dezembro de 2011. Dispõe sobre os procedimentos de controle e de vigilância da qualidade da água para consumo humano e seu padrão de potabilidade. Diário Oficial da União, Brasília, 14 dez. 2011, Seção 1, p. 39.

Brennan, S.K. \& Lowenstein, T.K. 2002. The Major-Ion Composition of Silurian Seawater. Geochimica et Cosmochimica Acta, 66: 2683-2700.

Brikmann, W.L.F. \& Santos, A. 1973. Natural waters in 
Amazonia. IV. Soluble Calcium Properties. Acta Amazônica, 3: 33-40.

Castany, G. 1971. Tratado practico de las aguas subterraneas. Barcelona, Ediciones Omega, 655p.

CETESB. Companhia Ambiental do Estado de São Paulo. 2010. Relatório de qualidade das águas interiores do estado de São Paulo, dados relativos a 1997. São Paulo, $289 \mathrm{p}$.

CETESB. Companhia Ambiental do Estado de São Paulo. 2014. Qualidade das Águas Superficiais no Estado de São Paulo. São Paulo, CETESB, 434 p.

CONAMA. Conselho Nacional do Meio Ambiente. 2005. Resolução CONAMA no 357 de 17 de março de 2005. Brasília: D.O.U. Disponível em: http://www.mma. gov.br. Acesso em: 10 de Junho 2014.

Custodio, E. \& Llamas, M.R. 2001. Hidrologia subterrânea. 2. ed., Barcelona, Ediciones Omega, 2v.

DAEE/UNESP. Departamento de Águas e Energia Elétrica/Universidade Estadual Paulista. 1980. Mapa Geológico do Estado de São Paulo. Convênio DAEE/ UNESP, Escala 1:250.000. São Paulo.

Furch, K., Junk, W.J. \& Klinge, H. 1982. Unusual Chemistry of Natural Waters from the Amazon Region. Acta Cientifica Venezoelana, 33: 269- 273.

Gaillardet, J., Dupre, B., Louvat, P. \& Allegre, C.J. 1999. Global silicate weathering and $\mathrm{CO}_{2}$ consumption rates deduced from the chemistry of large rivers. Chemical Geology, 159: 3-30.

Gibbs, R.J. 1972. Water chemistry of the Amazon River. Geochimica et Cosmochimica Acta, 36: 1061-1066.

Hem, J.D. 1985. Study and interpretation of the chemical characteristics of natural waters. USGS Water-Supply Paper 2254, 272p.

IPT. Instituto de Pesquisas Tecnológicas do Estado de São Paulo. 2000. Comitê de Bacia Hidrográfica do Tietê/Jacaré (CBH-TJ). Relatório Zero, UGRHI13: Diagnóstico da situação atual dos recursos hídricos $e$ estabelecimento de diretrizes técnicas para a elaboração do plano da Bacia Hidrográfica do Tietê/Jacaré. Araraquara: CBH-TJ, 502 p.

Mackereth, F.J.H., Heron, J. \& Talling, J.F. 1978 . Water analysis: some revised methods for limnologists. Cumbria, Freshwater Biological Association, 121p.

Man 561

Editores: Iran S. Corrêa e Maria do Carmo Lima e

Cunha.
Martinelli, L.A., Devol, A.H., Forbesberg, B.R., Victoria, R.L., Richey, J.E. \& Ribeiro, M.N.G. 1989. Descarga de sólidos dissolvidos totais do rio Amazonas e seus principais tributários. Geochimica Brasiliensis, 3(2): 141-148.

Meybeck, M. \& Helmer, R. 1992. An Introduction to Water Quality. In: Chapman, D. (Ed). Water Quality Assessment. Cambridge, University Press, 585p.

Miranda, E.E. (Coord.) 2005. Brasil em Relevo. Campinas: Embrapa Monitoramento por Satélite. Disponível em: < http://www.relevobr.cnpm.embrapa.br> Acesso em: 16 abril 2014.

Mortatti, J.\& Probst, J.L. 1998. Hidrogeoquímica de bacias de drenagem. Boletim IG-USP, Série Didática, v. 1, 239p.

Piper, A.M.A. 1944. A Graphic procedure in the geochemical interpretation of water analysis. American Geophysical Union Transactions, 25: 914-923.

Richey, J.E. 1985. The Amazon river system: a biochemical model. In: Degens, E.T., Kempe, S., Herrera, R. (Eds.), Transport of Carbon and Minerals in Major World Rivers. Hamburg, UNEP, p.365-378.

Sachs, L.L.B. 1999. Programa Levantamentos Geológicos Básicos do Brasil: Integração Geológica da Folha São Paulo. SF-23-Y-C. Estado de São Paulo. CPRM, Escala 1:250.000.

SIGRH. Sistema Integrado de Gerenciamento de Recursos Hídricos do Estado de São Paulo. 2005. Base Georreferencial; Pluviométrico. Disponível em: http://www.sigrh.sp.gov.br/cgi-bin/bdhm. Acesso em 14 de abril de 2014.

Smiler, R. 2014. Diagrames version 6.4. Logiciel d'hydrochimie multilangage en distribution libre. Avignon, Laboratoire d'hydrogeologie d'Avignon, disponível em: http://www.lha.univ-avignon.fr.

Stallard, R.F. \& Edmond, J.M. 1981. Geochemistry of the Amazon 1. Precipitation chemistry and the marine contribution to the dissolved load at the time of peak discharge. Journal Geophysical Research, 86: 98449858.

Winter T.C., Harvey, J.W., Franke, O.L. \& Alley, W.M. 1971. Groundwater and surface water: A Single Resource. U.S. Geological Survey Circular, v. 1139, 79p. 
